\title{
Contribuição Baiana à Filosofia Jurídica e à Sociologia do Direito.
}

\author{
A. L. Machado Neto \\ (Da Universidade da Bahia).
}

\section{Advertência.}

Fundada em 1891, a Faculdade de Direito da Universidade da Bahia logo se constituíu num centro de especulação jusfilosófica e de indagação sociológica como preocupações complementares ao puro tratamento técnico-dogmático do fenômeno jurídico.

Quanto à significação dos estudos de ordem sociológica, realizados nessa entidade acadêmica, baste citar o depoimento insuspeito do Prof. Thales de Azevedo que a ela atribui "os primeiros estudos e influências da sociologia na Bahia"1.

Se temos em vista que a filosofia em voga no Brasil, e, pois, na Bahia da época, era o positivismo, nas suas numerosas variantes, especialmente o evolucionismo spenceriano, veremos claro a impossibilidade de distinguir o sociológico do filosófico na produção intelectual daquele momento em tais setores da cultura.

Quem compulse os Estudos de Filosofia do Direito de Leovigildo Filgueiras e a Classificação dos Conhecimentos Humanos e das Sciencias Juridicas de Virgílio de Lemos ou, mesmo, o mais recence Prolegómenos à Ciencia do Direito

1. Thales de Azevedo, Nelson de Souza Sampaio, A. L. MaChado Neto, Atualidade de Durkeim, ed. da Univ. da Bahia, 1959, p. 7 (Introdução). 
de Edgard Sanches, verá claro, que, embora aparecessem como obras filosóficas, assinadas por professôres de filosofia juridica, o sociológico e o filosófico não apresentam fronteiras definidas no pensamento de teor naturalista e positivista dêsses iniciadores da sociologia e da filosofia jurídicas entre nós.

Diante da impossibilidade fáctica de proceder a essa separação, optamos pela solução óbvia de tratar os assuntos em conjunto, numa tentativa de compendiar o patrimônio cultural que representa para a Bahia a contribuição de alunos e professôres de nossa Faculdade de Direito na formação e elaboração da cultura sociológico e filosófico-jurídica na Bahia.

Para a realização dêsse empreendimento foi de especial oportunidade a ajuda prestada ao A. pela Fundação para o Desenvolvimento da Ciência na Bahia, que, dêsse modo, torna patente o fiel cumprimento da alta missão de que se acha investida pelas próprias finalidades explícitas da Instituição.

Também deve ser deferido ao Dr. Antonio Cabral de Andrade um especial agradecimento pelo modo como acedeu ao nosso convite para se ocupar do encargo assaz tedioso de compendiar a obra do A. para essa resenha.

\section{Período Inicial.}

Com a fundação da então Faculdade Livre de Direito da Bahia, criou-se, na Província um centro natural de aglutinação e elaboração do pensamento teórico voltado para os temas culturais da sociologia e da filosofia, destinado a desiocar o eixo da suserania intelectual nesses setores do único núcleo de atividade acadêmica que era, até então, a velha Faculdade de Medicina, onde resplenderam os talentos de um Eduardo Ferreira França (1809-1857) e de um Domingos Guedes Cabral (1852-1883).

O papel que representaram, na Colônia, o Colégio dos Jesuitas e os conventos de religiosos, e, no Império, a Fa- 
culdade de Medicina do Terreiro de Jesus, estava fadada, a nóvel academia jurídica, a representar na República, como centro de elaboração filosófica e de preocupação pelos problemas humanos e sociais.

Formados nas duas iniciais faculdades de Direito, os professôres na nóvel academia traziam de Recife e São Paulo a fermentação das novas idéias que acabávamos de importar da Europa como todos os bens materiais da cultura evoluída dos povos industrializados e cultos. Era a voga do evolucionismo de Haejel, do positivismo de Comte, do materialismo de BuchNFR, que, como reações ao pensamento tradicional, foram assimilados pela intelligentsia de um país colonial, como expressões ideológicas e quase religiosas de uma reação natural de descontentamento própria do inteIectual em face ao contexto social arcaico e dominado pelo espírito dogmático de progênie religiosa em que se acha enquadrada, contexto que lhes negava as oportunidades de um pensamento realmente original e criador.

$\mathrm{Na}$ "circunstância" provincial, essas novas idéias atuavam sob a forma espelhística, como um reflexo do reflexo, reproduzindo as influências dominantes nos centros mais evoluídos do País.

O pensamento dominante, na Província, nos setores da filosofia e da sociologia do Direito não poderia ser outro senão o pensamento vigente nos grandes centros intelectuais do País, graças à importação das idéias dominantes na Europa, por certo que com algum retardo natural ao pro.cesso de transplantação cultural.

Nenhum pensador original pode ser assinalado, mas não há negar que era grande o empenho daqueles iniciadores por estarem em dia com o que lhes parecia o mais significativo das contribuições do pensamento europeu no setor de suas especializações. Alguns dêles, como, por exemplo, Aliachio Disiz, chegaram a manter contactos diretos com as mais significativas expressões da filosofia naturalista européia da época, num empenho muito vivo por participarem ativamente da elaboração e da divulgação das novas 
idéias em nosso ambiente conservador, mas pleno de reverente admiração pelo ar iconoclasta do livre pensador capaz đa ousadia de empreender o combate franco e direto aos valores consagrados, especialmente os religiosos.

Mesmo nas tradicionais classes médias de rentistas, funcionários e profissionais liberais, que têm representado tradicionalmente um papel conservador, os arrojos anti-clericais e anti-religiosos dos porta-vozes das novas idéias encontravam admiradores, que, embora aderidos vitalmente aos valores tradicionais da comunidade conservadora em que viviam, valores pelos quais continuavam a orientar suas existências, não regateavam o aplauso às exterioridades do arrôjo e do brilho daqueles inovadores.

O panfleto, a polêmica e o jornalismo virulento tiveram sua voga mais representativa entre nós por êsse tempo, tendo-se, mesmo, tornado famosa a polêmica jornalística de um catedrático de Filosofia do Direito com um seu talentoso ex-aluno.

A vida intelectual - movida pela insinuante nota política que envolvia o combate das novas concepções agnósticas ou abertamente materialistas contra as resistências conservadoras da vida de Província - transformou-se em vida pública e o gôsto do discurso, tão característico da tradicional cultura baiana, contribuíu com sua parte para essa publicização da inteligência ou do talento, para usarmos uma palavra típica da época que comentamos.

Ocioso será assinalar o ar enciclopédico da cultura de então. As exigências da vida social pré-industrial não poderiam levar ao especialismo, senão ao poligrafismo. A variegada cultura de Ruy BARBosa - tratado pela imprensa da época com um luxo oriental de adjetivos encomiásticos, impossivel de se reproduzir hoje para um homem vivo era o exemplo dominante que todos desejavam imitar.

A gramática exercia uma verdadeira tirania sôbre as elites intelectuais. Uma incorreção na colocação dos pronomes estragava reputações. Enfim, o quadro intelectual que a Província exibía nesse tempo não poderia ser senão 
o mesmo quadro da vida intelectual na situação colonial, tal como no-lo descreve Roland Corbisier ${ }^{1 . a}$ Vieira Pinto ${ }^{2}$ e Gúrreiro Ramos ${ }^{3}$, apenas com as tintas mais carregadas no caráter ornamental e ostentatório da cultura.

Nesse ambiente pouco favorável à necessária interioridade e autenticidade da vida do espírito, a fundação da nóvel Faculdade de Direito iria lançar as raízes e uma tradição inicial de estudos filosófico e sociológico-jurídicos, cuja significação intrínseca talvez nos possa parecer, hoje, amesquinhada, mas cujo significado, como início de uma tradição intelectual que sòmente agora poderia começar a produzir os seus primeiros frutos, não pode ser desconhecido ou olvidado. Há que assinalar, em homenagem a êsses inovadores, que êles trouxeram ao ambiente estagnado da Província um considerável influxo de transplantação cultural sem o qual não se poderia esperar um ef etivo progresso teórico nesses setores.

Se aquí se acentuou o ambiente espiritual em que floresceu a sua meditação, nisso não houve sequer uma intenção crítica, mas antes a expressão da indispensável simpatia que há de conformar todo ato de compreensão. Se se assinala a circunstância pouco propícia em que exercitaram sua atividade intelectual, isso antes os exalta e valoriza do que os compromete ou minimiza. Numa província de um país ainda inteiramente dominado pelo que BaLANDiEr denominou de situação colonial, nada se poderia fazer de melhor que a transplantação cultural das novas idéias que vinham de dar à luz os grandes centros da cultura européia. Essa foi a tarefa que lhes coube, e êsse o seu grande mérito.

1.a. Roland CORBISIER, Formação e Problema da Cultura Brasileira, Ed. ISEB Rio. Rio.

2. Alvaro Vieira Pinto, Ideologia e Desenvolvimento, ed. ISEB,

3. Guerreiro Ramos, A Redução Sociológica, ed. ISEB, Rio. 
Leovigildo Filgueiras.

O primeiro nome a destacar num escôrco histórico da meditação filosófica e sociológica acêrca do Direito é o de Leovigildo (Ipiranga do Amorim) Filgueiras. Um dos fundadores da Faculdade, foi o primeiro ocupante da cátedra de "Filosofia e História do Direito"

Em seu livro Estudos de Filosofia do Direito, onde deixa patente a influência do evolucionismo spenceriano, não se logra perceber com nitidez a distinção existente entre filosofia do Direito e sociologia, malgrado os esforços do A. nesse sentido. Entendendo que a razão fundante da filosofia do Direito e o próprio título de sua diferenciação da "ciència geral da sociedade", a sociologia, é a "necessidade de uma disciplina que descubra, mediante o exame das suas formas mais simples e rudimentares, a origem do direito e, seguindo-lhe as fases históricas sucessivas, determine as leis que regulam a sua formação e o seu processo evolutivo" 4, Leovigildo Filgueiras não poderia apresentar melhor definição do que hoje se entende como o aspecto dinâmico ou histórico da sociologia jurídica.

Em verdade, os temas que propõe para a meditação filosófica sôbre o Direito são todos êles temas de origem e evoluçã̃o da realidade social-jurídica, e, como tais, temas de ciências de objetos empíricos como a sociologia e a história do Direito. É que ao filosofar naturalista - e, portanto, malgrado seu, embora, positivista - de Leovigildo Filgueiras, os temas mais autênticos da especulação jusfilosófica, como, e.g., o tema axiológico, não poderiam aparecer às suas vistas e às do ambiente espiritual em que viveu senão como temas metafísicos e, como tais, desleixáveis ou supérfluos, ao saber da moda positivista da época.

É que os supostos básicos em que se fundava - a classificação dos conhecimentos humanos que SPENCER divulgou em seu famoso First Principles - não lhe permitiam a visão

4. Estudos de Filosofia do Direito, M. Orosco \& Cia., Rio, 1904. 
clara da diferenciação entre o saber filosófico ("saber totalmente unificado"), e o científico ("saber parcialmente unificado") em tal sistemática apenas separados por uma questão de grau e não de essência.

E, assim, reduzindo a filosofia jurídica a uma "teoria geral da origem e evolução do direito" 5, Leovigildo FilgueiRAS, por maior que seja o seu empenho em diferenciá-la da sociologia, na verdade a identifica com um capítulo dinâmico da sociologia jurídica, ou, no máximo, reduz a especulação jusfilosófica ao capítulo da filosofia jurídica especial que Mrguel Reale denominou culturologia jurídica. E ainda mais se acentua aquela referida identificação quando escreve que "a filosofia do direito deve encontrar na sociologia o seu fundamento cientifico"6.

A linha geral do pensamento norteador dessa culturologia jurídica ou filosofia da história do Direito está orientada por uma síntese de evolucionismo spenceriano e otimismo iluminista que se casam numa visão otimista e progressista acêrca da evolução humana e do papel do Direito nesse processo como elemento civilizador.

Uma amostra suficiente dêsse progressismo otimista pode ser-nos proporcionada pelo seguinte trecho de sua obra acima citada:

"Considerada, pois, a evolução no conjunto do seu movimento histórico, vemos que reproduz perfeitamente os caracteres gerais que distinguem o desenvolvimento social, isto é, o predomínio progressivo dos fatores históricos sôbre os naturais, a eficácia cada vez mais freqüente das energias ideais acumuladas no curso do tempo, a parte sempre maior que tomam a reflexão e a vontade. Dahi vem que, à medida que se eleva o grau da intelligencia e da cultura, a consciencia collectiva elabo-

5. Op. cit., p. 194.

6. Op. cit., p. 200 
radora do direito vai adquirindo uma idéia mais clara, mais ampla e, sobretudo, mais reflexa das condições de existencia e dos fins por estas determinados" 7 .

Se ainda restasse dúvida quanto à composição evolucionista e iluminista de seu pensamento de progênie sociologista, um simples perpassar d'olhos sôbre o indice de sua obra, pela própria dominância dos temas sociológicos deixaria clara e confirmada a nossa assertiva acêrca da identificação de sociologia e filosofia jurídicas (essa última, por vêzes, apresentada como a ciência juridica) no pensamento do primeiro ocupante da cátedra de "Filosofia e História do Direito" em nossa Faculdade de Direito.

E até mesmo por essa identificação, e pelo largo conteúdo sociológico que se contém em seu compêndio, Leovigildo Frugueiras nos aparece como a primeira figura obrigatória dessa resenha por ambos os interêsses que ela persegue.

Virgilio de Lemos.

Após Leovigildo Filgueiras, a cátedra de "Filosofia e História do Direito" foi ocupada por VirgiLlo DE Lemos. Dono de uma personalidade vigorosa e lotado das qualidades espirituais do líder, Virgilio de Lemos exerceu na Provincia uma notável influência intelectual como portador e divulgador de idéias novas e de uma atitude racionalista e secular em face da vida.

Embora exercesse um verdadeiro fascínio sôbre seus discípulos - que, ainda hoje, lhe tributam uma entusiástica admiração - não se pode dizer que tenha feito escola. Nenhum discípulo notável lhe seguiu as pegadas deixando obra escrita em que sua influência intelectual pudesse ser convenientemente apurada. Também não foi um escritor fecundo, tendo deixado, apenas, como mais significativa

7. Id. ibd. 
contribuição escrita a lição inaugural intitulada $D a$ Classificação dos Conhecimentos Humanos e das Sciencias Jurídicas $^{8}$, publicada em 1916. Seu grande influxo foi, portanto, exercido verbalmente, o que talvez venha a explicar o fato de que seus discípulos - seguindo-lhe o exemplo também não tenham deixado obra escrita.

O evolucionismo spenceriano é a influência mais palpável em seu pensamento. E é da famosa classificação das formas de saber que nos legou SPENcER - embora que assumindo em face dela uma atitude crítica - que VirgiLIo dE LEMos vai se abeberar para produzir sua classificação geral dos conhecimentos humanos 9

E ainda inspirado em Spencer que êle refuta Comte naquilo de considerar em sua classificação do saber apenas os conhecimentos teóricos, excluindo os práticos, apresentando-nos a interessante sistemática dos conhecimentos humanos que se segue, e onde as ordens do saber estão representadas desde a especulação filosófica até o saber artístico inerente às artes e ofícios e o saber vulgar, como se pode verificar no quadro que se segue:

\begin{tabular}{|c|c|c|}
\hline $\begin{array}{l}\text { 1. }{ }^{\circ} \text { Quadro } \\
\text { (conhecimentos }\end{array}$ & filosóficos) & $\begin{array}{l}\text { A - filosofia geral } \\
\text { B - filosofias especiais }\end{array}$ \\
\hline $\begin{array}{l}\text { 2. }{ }^{\circ} \text { Quadro } \\
\text { (conhecimentos }\end{array}$ & formais) & $\begin{array}{l}\mathrm{C} \text { - lógica } \\
\mathrm{D}-\text { matemática }\end{array}$ \\
\hline $\begin{array}{l}\text { 3. }{ }^{\circ} \text { Quadro } \\
\text { (conhecimentos }\end{array}$ & abstratos) & $\begin{array}{l}\mathrm{E}-\text { mecânica } \\
\mathrm{F} \text { - física } \\
\mathrm{G} \text { - química }\end{array}$ \\
\hline $\begin{array}{l}4 .^{\circ} \text { Quadro } \\
\text { (conhecimentos } \\
\text { concretos) }\end{array}$ & abstrato- & $\begin{array}{l}\mathrm{H} \text { - astro-geologia } \\
\mathrm{I} \text { - biologia } \\
\mathrm{J} \text { - psicologia } \\
\mathrm{K} \text { - sociologia }\end{array}$ \\
\hline
\end{tabular}

8. Imprensa Official do Estado, Bahia, 1916.

9. Cfr., p. 11, op. cit.. 


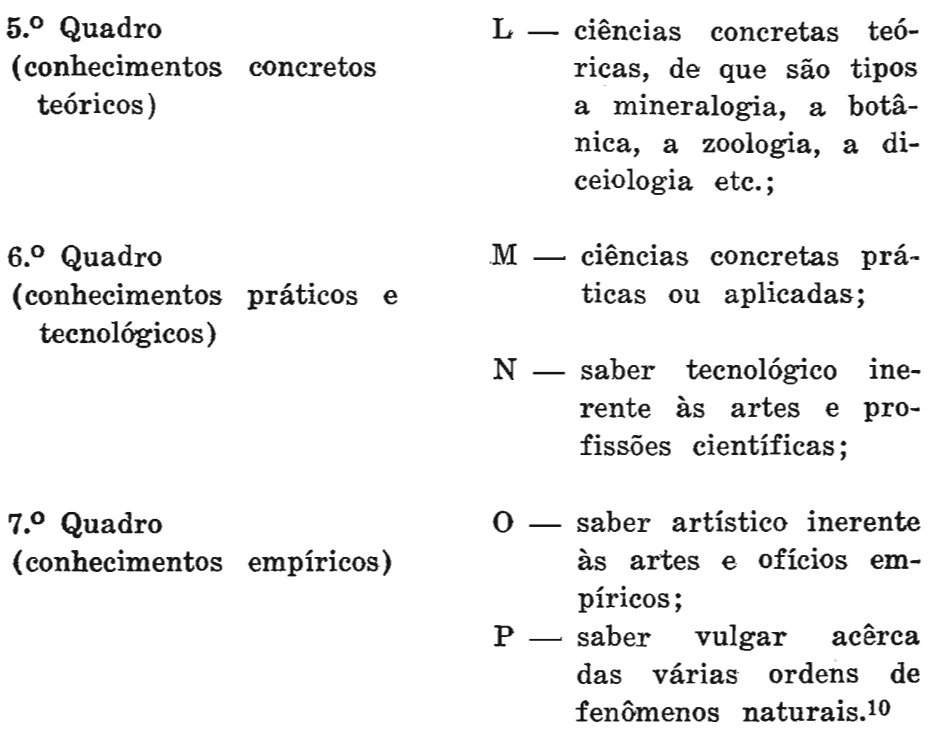
L - ciências concretas teó- ricas, de que são tipos a mineralogia, a botâ- nica, a zoologia, a di- ceiologia etc.;
M - ciências concretas prá- ticas ou aplicadas;
$\mathrm{N}$ - saber tecnológico ine- rente às artes $\mathrm{e}$ pro- fissões científicas;
O - saber artístico inerente às artes e ofícios em- píricos;
P - saber vulgar acêrca das várias ordens de fenômenos naturais. 10

Dentro dessa sistemática universal do conhecimento, onde se situaria o saber jurídico?

Quanto à dogmática, jurisprudência ou ciência jurídica no sentido estrito, VIrgILIo DE LEMos, após criticar severamente a omissão do jurista acêrca de sua problemática (op. cit., p.43), conclui que ela não é nem apenas uma ciência nem tão pouco sòmente uma arte ou técnica: "Com elle (Pedro Lessa) affirmo que a jurisprudência, ou dogmática jurídica, não é uma sciencia, mesmo quando, na linguagem empolgada de Jhering, a reputamos o precipitado da sã razão humana em matéria de direito" Mas também não a podemos considerar no seu conjunto integral uma pura arte, no sentido arido ou empirico desse vocábulo como parece reputal-o o dr. Pedro Lessa" (op. cit. p. 49).

No entender de nosso autor, a jurisprudência é a explicação de uma arte. E esclarece:

“A jurisprudência é justamente isso, porque representa, na arte juridica, aquela parte theorica, que todas as artes possuem, mais ou menos desenvolvida, e a do direito talvez

10. Cfr. op. oit., pp. 41-43. 
mais que todas, e que se superpõe à parte prática ou executória, para inspiral-a e fecunda-la, servindo de laço connectivo entre a arte propriamente dita e a respectiva sciencia de applicação, a que cada uma das artes scientificas se prende e se liga, conforme deixei reforçado, no passo onde refutei a opinião inconsequente e exagerada de Stuart Mill, perfilhada pelo dr. Pedro Lessa". (id. p. 50).

Assim caracterizada a jurisprudência ou ciência do direito, a técnica jurídica será por êle conceituada nos seguintes termos: "A arte jurídica pròpriamente dita, quero dizer, a parte prática da arte do direito, longe de caracterizar-se como uma "explanação", caracteriza-se como uma actuação, como uma realização, e consiste no complexo de actos e processos que tornam effectivas as regras, as normas, as determinações applicáveis a este ou aquele caso concreto" (p. 50).

Assim dividida a ciência jurídica em teoria e prática, êle muito a aproxima da sociologia como ciência abstrato-concreta da qual decorre essa forma de conhecimento concreto teórico que é a jurisprudência, denominada por nosso autor com o neologismo de diceiologia.

Ou, em sua própria expressão:

“ . esta ordem de estudos se subordina a uma categoria de estudos mais amplos e mais compreensivos, à categoria dos estudos sociológicos, porque afinal de contas, se o phenomeno jurídico é um phenomeno natural, é um phenomeno natural da categoria dos sociaes. A disciplina teórica que os corporifica é uma disciplina concreta, que está para a sociologia, como a botânica e a zoologia estão para a biologia".

E continúa:

"Que é botanica, senão o estudo da phenomenologia vegetal? Que é a zoologia, senão o estudo da phenomenologia animal? Nas mesmas condições, a sciencia concretoteórica do direito, a que chamariamos diceiologia, é o estudo da phenomenologia juridica". 
Aqui desponta o sociologismo jurídico de que VirgiLio DE Lemos seria, em nossa Faculdade, um elo de uma longa cadeia, que, iniciada em Leovigildo Filgueiras se estenderá até Nestor Duarte e Orlando Gomes, em nossos dias.

Quanto à filosofia do Direito, as idéias de Virgruo dE LEMos estão em plena consonância com a sistemática geral dos conhecimentos humanos acima apresentada.

Ela é, no seu entender, o estudo dos primeiros princípios, das idéias fundamentais relativas à ciência jurídica ou diceiologia.

Assim como a diceiologia se situaria no quinto quadro, e, provàvelmente a técnica ou arte jurídica, no sexto, a filosofia do direito como filosofia especial encontraria sua ubicação na letra $b$ do primeiro quadro.

"Em resumo, - poderiamos concluir com suas próprias palavras - o saber juridico se compõe de várias disciplinas de feições lógicas diferentes. Encarado com o critério gradativo, elle se decompõe em conhecimentos empiricos, artisticos ou technicos, representados pela jurisprudência, tomada esta palavra, quer no sentido lato, quer no seu sentido estricto; em conhecimentos scientificos, representados pela sciencia pratica ou aplicada, e pelas sciencias teóricas do direito; e em conhecimentos philosophicos, representados pela philosophia juridica. Apreciado com o criterio objectivo-genético, o saber juridico se filia às sciencias dos phenomenos sociais, ou à sociologia. Contemplado com o critério qualitativo, elle é um saber concreto, muito embora pela philosophia do direito se prenda também à ordem das sciencias constructivas e syntheticas". (p. 65)

\section{Almachio Diniz.}

O professor que sucedeu a VIRGILIo de LEMos na cátedra de "Filosofia e História do Direito" e depois catedrático de Enciclopédia Jurídica, Almacho Drniz, foi o mais prolifero dos autores que deverão ser considerados nessa sintese. Sua bibliografia é realmente espantosa, e foram muitos os campos do saber em que exerceu sua incansável atividade 
intelectual. Sua produção abrange não sòmente os setores da cultura teórica aqui considerados, mas também o direito positivo em seus vários ramos e especialidades, a etnologia, a filologia, o romance, a crítica literária, e, até, a própria literatura didática infantil.

No setor que aqui nos importa, sua bagagem bibliográfica é, já, bastante considerável, nela se destacando: Curso de Filosofia Elementar, Ensaios Filosóficos sobre o Mecanismo do Direito, Questôes Actuais de Philosophia do Direito, Sociologia Soviética. Uma Objetividade nova do Direito: o Direito dos Soviettes, e A Idéia Revolucionária nos Meus Princípios Filosóficos.

Sua orientação filosófica é o evolucionismo em sua fórmula monística segundo os princípios de HAECKEL.

Desde o ensaio que o próprio autor, em dedicatória a seu progenitor, qualificou como seu "primeiro esfôrço scientiphico", que essa predileção pelo monismo haeckeliano é proclamada, não sem certo acento que hoje não poderia deixar de nos parecer ingênuo. Dêsse ensaio colhemos essa preciosa profissão de fé filosófica que, ao menos em suas linhas gerais, não foi desmentida por tôda a sua vida:

" $\mathrm{Eu}$, por mim, adoto a efficacia e a intelligibilidade da gravitação exercida como o equilibrio dos astros, e, por isso, poderia fazer minhas as considerações de Herbert Spencer, no sentido de que "se o espaço é uma forma do não ser, deve produzir no eu alguma forma universal correspondente", que é, para Fausto Cardoso, a consciencia. Ainda mais: adopto o mecanicismo dos mundos, que é o verdadeiro monismo naturalístico de Haeckel, descrendo della e abominando a metaphysica philosophica do monismo de Noiré; estou certo, finalmente, de que, por effeito do monismo universal, ha o direito no mundo social, ou dos homens, como uma relação de equilibrio, da mesma forma que no mundo sideral ou sociedade dos astros, há a gravitação, no mundo physico ou organico, ha a vida, e no mundo physico, ou das intelligencias, ha a consciencia. Ahi está a minha philosophia! 
- Evohé! philosophia mecanicista dos mundos sem dogmas nem preconceitos religiosos"11.

Em sua concepção mecanicista do fenômeno jurídico, os traços naturalistas e monistas dessa profissão de fé filosófica não desaparecem, mas, ao contrário, se afirmam e solidificam.

Também a desassombrada e polêmica atitude anti-clerical e, até mesmo, anti-religiosa, que, naquele pronunciamento, se revela, vai ser outra nota dominante da atividade intelectual e da própria vida e conduta do nosso autor. A êsse respeito é curioso anotar - como expressão do estado de espírito da intelectualidade de uma época já superada da evolução espiritual baiana - a seguinte notícia que aparece em uma de suas obras, como anúncio de seus romance de idéias A Carne de Jesus:

"A Carne de Jesús - novella histórica, ellogiada por Max Nordau, com excomunhão do Senhor Arcebispo da Bahia - Brochura com gravuras (No Prelo)".

O modo como o elogio de Max Nordau é contrastado com a exibição da excomunhão do Arcebispo da Bahia qualifica, de forma típico-ideal, a figura a um só tempo receiada e furtivamente admirada do livre pensador capaz de arrostar as punições canônicas como um galardão a mais, por sí só capaz de garantir a bôa qualidade de um produto intelectual. Se hoje essa conduta nos pode parecer “demodé" e infantil, não há como negar a sua significação polêmica num momento en que era preciso espantar o marasmo confessional, que dominava o pensamento eminentemente tradicionalista e dogmático da Província para permitir-lhe a assimilação do pensamento novo, de conteúdo naturalista, que a Europa exportava àquele tempo.

Ninguém o fêz com maior calor emocional e - quem sabe?! — com ânimo mais religiosamente apostólico do que êsse extraordinário amigo baiano de Max Nordau.

11. Questões Actuais de Philosophia do Direito, H. Garnier, Rio, 1909, p. 174. Genesis Hereditaria do Direito, Bahia, 1903. 
Edgard Sanches.

O derradeiro nome a considerar nesse periodo inicial é do Prof. Edgard Sanches.

Em sua tese de concurso para a cátedra de Filosofia do Direito, intitulada Prolegomenos à Sciencia do Direito, o tema epistemológico é o dominante, como aliás sugere o seu título.

A orientação geral que o domina é a mesma que dirige o pensamento de seus antecessores, embora mais atualizado. O evolucionismo spenceriano ou haeckeliano foi superado pela filosofia francêsa das ciências dominantes na época - Binet, Ribot, Poincaré, Charles Blondel, Lachellier, Boutroux, Bergson. Também o neo-positivismo de Mach e o pragmatismo de William James deixam a marca de seu influxo sôbre o pensamento do prof. Edgard SANches.

Seu ponto de partida gnoseológico é o mais extremo e radical empirismo:

"A lógica é um sistema abstracto de principios tirados da experiência, princípios que são as relações necessárias mais gerais dos fatos, traduzidos na ordem intellectual das idéias" 12 .

Não poderia haver mais franca negação dos objetos ideais. E, dessa negação, a fatalidade da inclusão da ciência do direito como ciência de objetos reais naturais, como, aliás, parece são tôdas as ciências no entender do notável professor.

"A sciência juridica ha de ser o estudo do phenomeno juridico, praticado da mesma maneira que o dos demais phenomenos da natureza.

Ha de estudar o direito como a matematica estuda a grandeza, como a physica estuda a materia, a chimica o elemento, a biologia estuda a vida, a psichologia, os factos psychicos, como estuda a sociologia os phenomenos sociais" 13 .

12. Edgard SANches, Prolegómenos à ciencia do direito - Imprensa Official do Estado, Bahia, 1927, pp. 12-13.

13. Op. cit., p. 103. 
Através desta citação é fácil depreender que o prof. Edgard Sanches identifica a matemática às ciências de objetos naturais como conseqüência, aliás, decorrente de sua anterior "empiricização" da lógica e negação implícita dos objetos ideais.

A partir dêsses pressupostos, não poderia fugir ao sociologismo como posição epistemológica face à jurisprudência. E essa não é apenas uma conclusão deixada à inferência do leitor, senão que uma confissão patente do Autor na página de Advertência que encabeça a sua tese:

"Chamamos sciencia do direito o a que certos autores têm denominado philosophia do direito, e Nardi Greco sociologia juridica (p. I).

Também nesse quarto nome de periodo inicial não há, pois, com estabelecer a distinção entre o sociológico e o filosófico-jurídico em seu pensamento.

Aliás, esta que foi a perspectiva dominante na fase inicial prolonga-se de maneira inercial na intermediária, constituindo, mesmo, uma preocupação dominante no período crítico e renovador que êsses estudos estão vivendo presentemente entre nós.

\section{O Período Intermediário.}

Os quatro nomes cuja obra comentamos no capítulo anterior representam, na história da meditação teórica sôbre o fenômeno jurídico na Bahia, o período heróico de fundação dêsses estudos na Província.

A fase que se segue, e que preenche as décadas dos trinta e dos quarenta, é, a êsse respeito, um período tranqüilo em que os discípulos daqueles primeiros arautos das idéias inovadoras de progênie naturalista podem recolher os louros da conquista, prolongando as linhas da meditação cientificista que vão do evolucionismo spenceriano ao haeckeliano e do positivismo comteano ao sociologismo durkheimiano e ao economicismo marxista. Naquela po- 
sição encontramos Nestor Duarte, atual catedrático de "Introdução à Ciência do Direito", cadeira que substituíu a destronada Filosofia do Direito nesta última, OrLando Gomes, hoje o nome mais prestigioso das letras juridicas baianas, e, intentando uma sintese das duas posições em composição com certas contribuições mais recentes do pensamento filosófico, Hermes Lima, docente de nossa Faculdade, mas, como tantos outros baianos ilustres, atraído pelo Rio de Janeiro, onde exerce as funções de catedrático de Introdução à Ciência do Direito da Universidade do Brasil.

Tal como o primeiro periodo representou o transplante das novas ideologias naturalistas de recente aparição na Europa, êsse segundo reproduz, em nosso meio, os efeitos anti-filosóficos que a vigência do positivismo determinou na Europa à sua hora.

Entre nós, êsses efeitos anti-filosóficos foram institucionalizados através da supressão das cadeiras de Filosofia nos cursos secundários e das de Filosofia do Direito nos cursos jurídicos.

Num período de post-revolução, ditadura e guerra, a sociologia apareceu como a panacéia eminentemente organizadora capaz de resolver todos os problemas e atrair tôdas as atenções, como legitima sucessora da destronada e morta filosofia jurídica. Não terá sido por acaso que o mais significativo evento da história literária nacional seja, nessas duas décadas o romance social nordestino, movimento em que, aliás, está envolvido o prof. Nestor Duarte, através de seu romance Gado Humano.

Nestor Duarte.

Em sua tese de concurso para a cátedra de Introdução à Ciência do Direito, intitulada O Direito, Noção e Norma e no artigo doutrinário Os Fundamentos do Direito Natural e as Direcões do Positivismo Jurídico, publicado na Revista da Faculdade de Direito da Bahia, (v. 16, 1941) resume-se o essencial da produção intelectual do professor Nestor 
Duarte no que nos diz respeito nessa resenha. Em setores próximos do nosso interêsse central nesse trabalho, o mestre de introdução à Ciência do Direito publicou também um exitoso ensaio sociológico sôbre A Ordem Privada e a Organização Política Nacional (Contribuição à Sociologia Política Brasileira), em que analisa a grande dominância da ordem privada, representada na familia patriarcal, sôbre a organização política de nosso País, e A Reforma Agrária, fundamentação de um projeto legislativo de sua autoria sôbre o momentoso e controverso tema. Sua obra de romancista, iniciada com o romance social (Gado Humano) acima referido, foi recentemente reencetada com a publicação de um romance de idéias que pretende retratar as angústias e as vacilações ideológicas dos intelectuais brasileiros nesses Tempos Temerários ${ }^{14}$.

O pensamento jurídico do prof. Nestor Duarte iniciase com o dilema da escolha entre filosofia ou sociologia do direito. Esse dilema êle o transporta para o primeiro capítulo de sua tese de concurso.

\section{Orlando Gomes.}

Se o sociologismo durkheimiano é a inclinação predominante da obra do prof. Nestor DuArte, o materialismo histórico é a nota dominante da já considerável obra jurídica do prof. Orlando Gomes.

Iniciando, ainda muito jovem, a sua carreira intelectual com uma tese à cátedra de Introdução à Ciência do Direito, intitulada $O$ Estado $e$ o Individuo, o prof. Orlando Gomes orientou-se, depois, para o direito positivo, especializando-se em direito civil e direito social ou do trabalho, disciplinas de que é, hoje, catedrático nas Faculdades de Direito e Ciências Econômicas, respectivamente.

Malgrado essas especializações pròpriamente jurídicas, o prof. Orlando Gomes jamais pôde eludir os impulsos teoréticos de sua vocação inicial, e, mesmo em seus livros de

14. Ed. da Livraria José Olympio, Rio, 1958. 
direito positivo, largos parênteses sociológicos e, às vêzes, filosóficos, permeiam a sua rigorosa exposição dogmáticojurídica.

Outrossim, em sua bagagem literária, de permeio a ensaios e tratados de direito civil e trabalhista, sempre despontam lúcidos opúsculos e claros ensaios de teor evidentemente sociológico-jurídico que lhe garantem a palma de o mais lúcido e objetivo sociólogo baiano do direito. Nesse caso estão os seus livros A Crise do Direito ${ }^{15}$ e Raízes Históricas e Sociológicas do Código Civil Brasileiro ${ }^{16}$ e os opúsculos Materialismo Histórico e Direito, As Classes Sociais na Formação do Direito, Variações Sôbre a Reforma do Código Civil, A Evolução do Direito Privado e o Atraso da Técnica Jurídica, todos editados pelo Centro Acadêmico Ruy Barbosa, órgão oficial dos acadêmicos de nossa $\mathrm{Fa}$ culdade.

Num terreno fronteiriço, mais que isso, indeciso, entre a filosofia e a sociologia jurídicas situa-se sua recente obra intitulada Marx e Kelsen ${ }^{17}$.

Se deixamos de parte sua tese de concurso à cátedra de Introdução à Ciência do Direito, obra juvenil de exposição entusiástica das teses de Marx sôbre o fenômeno jurídico, o mais significativo da produção sociológico-jurídica do prof. Orlando Gomes está compreendida nos ensaios que enfeixou no livro $A$ Crise do Direito e no inspirado pequeno grande livro sôbre as Raízes Históricas e Sociológicas do Código Civil Brasileiro.

No primeiro, o tema dominante é a sociologia do direito individualista e sua decadência ( $A$ Elegia do Código $\mathrm{Na}$ poleão) em face das novas condições objetivas que a revolução industrial, e sua conseqüência jurídica - o direito social - vêm determinando.

15. $1 .^{\mathfrak{a}}$ ed., Papelaria Vera-Cruz. Bahia, 1945.

16. Ed. da Liv. Progresso, Ed. Universidade da Bahia, Bahia; 1958.

17. Ed. da Liv. Progresso, Ed. Universidade da Bahia, Bahia. 1959. 
Esse "Leitmotif" não abandona inteiramente a sua meditação histórico-sociológica sôbre as raízes do nosso Código Civil. Esta obra situa-se, em rigôr, no campo da sociologia jurídica de nossas instituições positivas, onde o docente de Introdução à Ciência do Direito, e, portanto, professor de sociologia jurídica, compõe-se em harmoniosa unidade com o catedrático de direito civil e direito social.

Após sumariar brevemente a formação histórica de nosso direito privado, salientando aí a grande influência do direito civil português graças à longa vigência entre nós das Ordenações filipinas, que regulava ainda muitos aspectos de nossa vida civil após sua revogação em Portugal, nosso Autor passa ao aspecto sociológico de sua pesquisa, acentuando, na esteira de Oliverra Vianna e Nestor DUARTE, a predominância da "ordem privada" ou do "privatismo doméstico" em nossa formação jurídico-política, privatismo que é solidário da predominância do rural sôbre o urbano a que nos condicionou nossa economia eminentemente agrária até há bem pouco tempo.

O seguinte capítulo traça-nos um quadro das linhas mestras da estrutura social do País no periodo de elaboxação do código, que nos apresenta a coincidência dos interêsses coloniais e anti-desenvolvimentistas das duas mais ponderáveis camadas da elite nacional — a burguesía latifundiária e a burguesia mercantil - coincidência apenas levemente perturbada pelos ímpetos idealistas das camadas intelectualizadas e urbanas da classe média, que, seguindo velho sestro nacional, procurava transplantar para o Pais as instituições individualistas do direito europeu, que então começavam a sofrer os primeiros solavancos reformadores em seu próprio solar pátrio.

O Código Civil nos aparece, então, como uma obra de transição entre os arrojos individualistas dêsses intelectuais da classe média - arrojos bafejados pelo apoio da burguesia urbana e mercantil que enxergava no liberalismo econômico a ideologia a mais compativel com a expansão de seus interêsses - e a ação conservadora dos representantes 
da burguesia rural e agrária "que não toleravam certas ousadias" (p. 48).

Procurando, em seguida, sondar o grau de adaptação do Código Civil aos novos rumos do direito privado desenvolvidos pelo agravamento da questão social, mostra-nos a nenhuma ressonância que suscitavam em nosso meio, nos começos do século, as progressistas tentativas legislativas de especial proteção ao trabalhador, seja regulando especialmente a locação de serviço, seja os acidentes do trabalho para concluir que "é certo que as condições materiais do país não forneciam a introdução de principios avançados na época" (p. 66).

Concordando, embora, que era cedo demais --- dado o subdesenvolvimento do País - para a plena adoção dos principios básicos do direito do trabalho, lamenta, entretanto, que o nosso Código Civil se mostrasse reacionário a certas conquistas trabalhistas já bastante divulgadas na época.

Concluindo, assinala certo descompasso entre o direito escrito e a realidade social, descompasso proveniente de ter-se o código colocado, via de regra, algo acima da realidade brasileira, "incorporando idéias e aspirações da camada mais ilustrada da população" (p. 71), não se esquecendo de salientar, todavia, que algo depois da primeira guerra mundial êsse descompasso se anulou, pois a realidade social logo evoluíu no sentido de alcançar sua legislação progressista.

No setor da filosofia jurídica, a obra principal do prof. Orlando Gomes é um pequeno trabalho recente intitulado Marx e Kelsen, no qual, em visivel atitude polêmica, o A. intenta mostrar a incompatibilidade do pensamento jurídico dêsses dois autores, mais uma vez definindo-se pelo materialismo histórico.

A suposta contradição invencivel de quem intentasse associar o purismo jurídico de Kelsen, em matéria epistemológico-jurídica, e o materialismo histórico, em sociologia juridica, decorre de o prof. Orlando Gomes ter encarado as 
duas doutrinas como se elas se situassem no mesmo plano lógico, o que, evidentemente não acontece, uma vez que o marxismo é dominantemente uma ontologia sociologista ou economicista de direito, enquanto a obra de KELSEN, um típico neo-kantiano, situa-se nos domínios da epistemologia jurídica ou teoria filosófica da ciência do direito. Daí decorre, pois, que se dissolva a contradição invencivel apontada pelo autor de MARX e KELSEN, uma vez que a mesma palavra - direito - tem, no materialismo histórico e na teoria pura, uma significação diversa, ou melhor, são coisas distintas.

O que Marx chama direito seria para Kelsen, dada sua intenção purista, uma impureza, uma série de fenômenos naturais que não constituem objeto da ciência jurídica.

Ao contrário, o que Hans Kelsen designa com tal nome, ou é a ciência do direito - e não há como confundir uma ciência com seu objeto - ou é o objeto da ciência jurídica já depurado de impurezas de tôda ordem (inclusive o econômico e os fenômenos de ordem ideológica) por uma especial atitude metodológica, em termos a permitir o tratamento científico do mesmo.

O fato, pois, de que Kelsen, num empenho visivelmente epistemológico, queira purificar o jurídico de tôda impureza extra-normativa não impede que um kelseniano - ao menos não ortodoxo, já que não é bem nítida a posição do mestre de Viena face aos títulos de cientificidade da sociologia jurídica, embora a opinião mais sustentável seja a de que êle aceite a possibilidade dessa especialidade sociológica possa aceitar (como atitude metodológica essencial para construir a ciência jurídica) que o direito que interessa à jurisprudência seja a norma em sua pureza, embora reconheça a possibilidade de prolongar o estudo do jurídico em termos sociológicos, perspectiva em que lhe está facultada a adoção do materialismo histórico, malgrado a superação dêsse sistema ideológico em tantos aspectos pela sociologia do século $\mathrm{xx}$. 


\section{Hermes Lima.}

Como já ficou acima referido,-o prof. Hermes Lima, decente-livre de nossa Faculdade de Direito tornou-se catedrático de introdução à Ciência do Direito na Faculdade de direito da Universidade do Brasil e Ministro do Superior Tribunal Federal.

A consideração de sua obra nessa resenha deve-se ao fato de que as raizes ideológicas de seu pensamento estão ainda profundamente ligadas ao sociologismo imperante, na Faculdade de Direito da Bahia.

Outrossim, foi na Bahia que o ilustre mestre iniciou sua produção intelectual com uma tese intitulada Conceito Contemporâneo de Sociologia, com a qual concorreu à livre docência de Sociologia do então Ginásio da Bahia.

Nesse trabalho que não apresenta outro mérito senão o de ser uma divulgação de teses e doutrinas sociológicas de Comte e Durkheim e Levy Bruhl, pode-se já notar a inclinação sociologista que o $\mathrm{A}$. herdou da tradição acadêmica da Faculdade de Direito e que iria permear o seu pensamento filosófico e sociológico-jurídico hoje compendiado nas várias edições de seu Introdução à Ciência do Direito.

Nesse último livro, a obra sôbre a matéria mais divulgada no país, a posição sociologista e para-marxista do $\mathbf{A}$. impede-ihe a visão do caráter eminentemente epistemológico (sem prejuízo de ser também sociológica, já que o seu teor é enciclopédico) da disciplina introdutória à ciência jurídica. Isso faz com que o professor da Universidade do Brasil realize as transposições bastante arriscadas a que o sociologismo se obriga, por falta de uma rigorosa atitude epistemológica, não tomando conhecimento das fronteiras existentes entre o tratamento sociológico, o filosófico e o pròpriamente jurídico.

A obra e a atividade intelectual do prof. Hermes lima como pensador, ideólogo político e fino comentarista e intérprete dos eventos políticos e sociais do presente brasileiro não se esgotam no setor a que aquí nos restringimos por 
imposição temática; e isso é uma lástima porque assim, dêsse homem realmente excepcional, arriscâmo-nos a perder o melhor pedaço. Mas desgraçadamente, assim tem que ser por imposição irrecorrível do nosso tema.

\section{O Período Crítico.}

Não se pode dizer que a Bahia intelectual esteja vivendo, hoje, um período áureo. Isso não quer dizer, porém, que outro período tenha havido em sua história que superasse o presente em atitude crítica e floração intelectual. Aliás, nesse aspecto, mais uma vez a velha Província reflete o panorama nacional como um fiel espelho.

Também aquí a quebra dos velhos padrões retóricos e grandiloqüentes se está verificando em favor de uma cultura mais integrada na realidade nacional e local, que não vacila em sacrif́icar o ornamental pelo instrumental. Também os estilos culturais estão se transformando em favor da especialização e em detrimento do onisciente bacharelismo. De qualquer sorte um ambiente novo agitado por uma inédita fermentação cultural revolve a Província, atingindo até as gerações mais novas, nas quais alguns nomes já repontam tendo já uns a seu crédito promissoras realizações culturais e outros tantos justificando as mais sólidas esperanças.

No terreno que nos importa considerar nesse trabalho, o marco mais significativo das transformações que se operam nessa Província pode ser identificado com o início da docência universitária do prof. Nelson de Souza Sampaio, que é, assim, pois, o primeiro nome a considerar nesse período.

Nelson de Sousa Samparo

Salvo alguns artigos juvenis, a obra do prof. Nelson Sampaio se inicia com a publicação de sua tese sôbre $A s$ Idéias Fôrças da Democracia, com a qual obteve a docência livre de Teoria Geral do Estado. 
Nêsse livro, seguindo o processo do condicionamento imanente das idéias, pesquisa as vinculações conceituais das teses que conduzem à democracia ou aos sistemas políticos anti-democráticos.

De 1941, data da publicação dêsse trabalho, até 1951, quando aparece $A$ Desumanização da Politica, a atividade intelectual do prof. Nelson Sampaio foi dominantemente voltada para a docência universitária - alcançada com aquela tese - onde exerceu extraordinária influência sôbre a nova geração, no sentido de uma atitude intelectual menos grandiloqüente e mais crítica, com o que contribuíu de maneira singular para a desprovincianização da vida intelectual baiana nos setores próximos de sua atuação.

Com a publicação de $A$ Desumanização da Política o prof. Nelson Sampaio passa a explorar em livro o meio mais rico de sua contribuição docente que é a meditação epistemológica sôbre o politico, que iria culminar em sua dissertação de cátedra significativamente intitulada Ideologia e Ciência Politica.

Já naquele primeiro ensaio dedicado ao tema, a investigação epistemológica - que o conduziu ao estudo dos irracionalismos políticos que ameaçam destroçar a meditação coerente e sistemática sôbre o político, erigindo a violência em lugar da discussão liberal como processo consagrado do êxito político - deixa-se permear por uma inflexão moralizante e humanista de um racionalista liberal, que dirige sua meditação sôbre os condicionantes irracionais da ação e da teoria políticas num sentido que, nesse aspecto, poderíamos chamar socrático, porque inspirado na mais desenganada crença na razão e na sua possibilidade de organizar o mundo ético-político em termos de individualismo e humanismo.

Num mundo de decadência do liberalismo, sua análise do curso histórico ascendente dos irracionalismos políticos não pode concluir senão pelo pessimismo lamentoso que se depreende dessa página final de $A$ Desumanização da Política: 
"Houve época em que a conduta política obedecia à revelação. Em outra, foi a razão quem se arrogou dirigí-la. Agora, os instintos ou impulsos parecem reivindicar essa tarefa. A parte sub-humana do homem, como um Incitatus vitorioso, se eleva a árbitro e inspirador do govêrno.

Porisso mesmo, o ruído das passadas do Leviatã parecem, por vezes, abalar o edificio da civilização, e nos estremecem em meio dos nossos pesadêlos, dando-nos a impressão de que aquêle centauro microcéfalo se transformou, afinal, num centauro decapitado, a cavalgar desenfreado, dentro da noite, em plena fúria das paixões e dos instintos".

Dêsse desencanto pessimista com o presente sai o Mestre por dois caminhos igualmente idealistas e racionalistas. Um é a pregação oratória das excelências da democracia como A Arte de Ser Livre, título sugestivo de uma pequena coletânea de três discursos, editada pela Progresso em 1957.

$O$ outro é o que já assinalamos como o mais significativo de sua meditação e de sua docência, o seu mais alto legado intelectual à nova geração baiana - é o filão epistemológico. E êsse está dignamente representado na obra com que se apresentou candidato ao último escalão da dignidade universitária - Ideologia e Ciência Política.

Esse livro, que constitui, até aquí, a obra máxima do prof. Nelson Sampaio, percorre os mesmos caminhos que A Desumanização da Política desbravou, é verdade que já num âegulo de maior purificação epistemológica, porque mais desprendido da preocupação moralizante ou ética.

São ai analisados - com uma segurança e uma seriedade que fariam a glória de qualquer schollar europeu ou americano dos melhores centros universitários - todos os grandes teóricos do irracionalismo político, desde os sofistas até Pareto e Spengler, sem esquecer a relativização do saber político decorrente das investigações da psicanálise, do marxismo e da sociologia do conhecimento.

Após essa análise, o argumento contra o cético é utilizado como arma definitiva que expõe à luz da razão a con- 
tradição em que se debatem êsses negadores de uma saber universal sôbre o politico, mas que acabam todos encadernados nos compêndios de história das idéias políticas, porque não se furtam à aventura de proporem mais uma teoria sôbre a sociedade, o Estado e a vida política em geral.

Limpando, assim, o terreno pela auto-destruição de todos os relativismos políticos, passa o Mestre à segunda etapa de sua investigação, à pròpriamente positiva ou construtiva, que seria a de fundamentação dos títulos de cientificidade da suposta ciência política.

Nesse ponto, porém, deixa muito a desejar a sua investigação epistemológica, porque não chegou jamais a precisar o conceito de ciência política e mostrar-lhe os títulos de cientificidade como disciplina autônoma, diversa portanto do direito político, de história política e, particularmente, da sociologia política. Nesse ponto, prevaleceu em seu espirito, parece, um prestígio não devidamente analisado. Referimo-nos ao fato de as universidades e os teóricos americanos denominarem de Ciência Política algo muito próximo daquilo que, com maior rigor epistemológico, denominamos de Teoria Geral do Estado, em nossas faculdades de Direito, ou de apenas Politica em nossas faculdades de Filosofia.

Por certo que para se falar de Teoria Geral do Estado como um saber enciclopédico, englobando, a um só tempo, as investigações da filosofia política - que, por suposto, não é uma ciência, por ser filosofia - da história política, do direito político e da sociologia política, e apenas para rebater o excessivo relativismo dos irracionalistas políticos em termos tais que justifiquem a preocupação com aquêle saber enciclopédico ou com cada um dos seus setores, a argumentação anti-relativista do Mestre tem plena procedência. A nada mais do que a isso se achava êle obrigado numa tese de concurso para a cadeira de Teoria Geral do Estado.

A expressão ambiciosa de Ciência Politica, herdada da iradição universitária americana que o Mestre freqüentou 
numa bôlsa de estudos anterior à sua docência, prejudicou visivelmente a pars construens daquele livro marcante.

$\mathrm{E}$ isto porque o político, pelo caráter decisional que envolve, é visceralmente valorativo, e, portanto, incompatível com o tratamento científico, ao menos para quantos enxergam - como Mestre Nelson Sampaio tão bem soube transmitir a seus alunos - no princípio de neutralidade axiológica a pedra de toque do saber da ciência.

Dir-se-ia que nada impede o tratamento factual dos valores, inclusive os políticos, mas que outra coisa poderia ser isso senão sociologia política?

À parte, pois, do que seja histórico, sociológico ou jurídico, nada há no político senão aquêle irredutível conteúdo valorativo que repele o tratamento científico, inscrevendo-se, assim, no seu grau mais elevado, no setor do pensamento filosófico, e em dimensões menos egrégias e até algo mal vistas pelo moralismo idealista do Mestre, como técnica ou arte política.

Dir-se-ia, talvez, que ciência política, como a entendem os americanos não é senão um outro rótulo intelectual quiçá mais pomposo - para as investigações de sociologia política.

Mas, essa não seria uma escusa em termos a justificar todo o grande esfôrço epistemológico empreendido nesse livro realmente magistral. De fato, para perserverar num equívoco terminológico não valeria a pena uma abordagem crítica - como a empreendida em Ideologia e Ciência Política - a tôda a estrutura de relativismo político, desde suas raízes sofísticas até sua fronde científica com a psicanảlise e a sociologia do conhecimento. Há aí, pois, uma visivel decadência do mais alto filosofar, exibido na pars destruens, para o mais elementar senso comum em que conclui a pars construens. $\mathrm{E}$ isso, quer-nos parecer, tem raízes mais profundas do que as aparentes, na personalidade do prof. Nelson Samparo e na sua ubicação histórica e generacional, capaz de arrojar alguma luz sôbre o problema 
histórico da evolução intelectual dessa Província nos setores que aqui nos são afetos.

Para efeitos meramente metodológicos, resumiremos em duas ordens de razões e explicação que aventuramos a seguir :

a) Razões de ordem histórico-generacional.

b) Razões de ordem política.

No item a queremos sintetizar a trama de relações generacionais em que se viu envolvido o Prof. Nelson Sampaio quando iniciou sua meditação e sua atividade docente. Constatando a total entrega dos seus antecessores teóricos na Faculdade de Direito às florações da filosofia naturalista e positivista do século passado e tendo em mira colocar-se à altura dos tempos, o mestre de Teoria Geral do Estado se propõe absorver, com prevenida atitude crítica, a filosofia anti-positivista que se seguiu, na Europa, ao baixar-mar do ciclo naturalista que dominou a paisagem espiritual da passada centúria. Com isso, conseguiu, de fato, semear na Bahia as novas tendências doutrinárias, em particular as da filosofia dos valores. O excessivo espírito crítico com que pretendeu superar o ingênuo dogmatismo de seus predecessores perdeu-o, porém, para tôda afirmação doutrinal de cunho teorético que vá além do chão comum do liberalismo tradicional em matéria política e de um racionalismo inspirado no senso comum. Èsse não chega a ser um ponto de vista pessoal, com ser a própria matriz de que originàriamente há que partir quem comece a sua meditação do contexto em que se situa o nosso autor.

A fidelidade a êsse ideal comum de sua juventude - o liberalismo - herança política inconteste do pensamento teórico de nossa Faculdade em tal matéria, embatendo-se com um mundo cada dia menos liberal não poderia resultar senão em pessimismo e abandono ou fuga da realidade.

Em face de um Brasil e de um mundo que teimava em apartar-se, cada vez mais, da doutrinação liberal, Mestre Nelson Sampaio refugiou-se no mundo das idéias onde, 
porem, o seu espírito exacerbadamente crítico e a sua demissão da prática ${ }^{18}$ não lhe permitem o engajamento a qualquer posição filosófica, contentando-se, assim, com a segurança tranqüila do senso comum, do que a conclusão final de Ideologia e Ciência Politica nos proporciona um exemplo significativo.

Dessa sua rejeição teórica da realidade pode servir de exemplo a conferência que sôbre As Doutrinas Políticas Contemporâneas e suas Relações com a Segurança Nacional pronunciou a convite da Escola Superior de Guerra.

$O$ exemplo é extraordinàriamente significativo pelas circunstâncias singulares que cercam o aludido estudo.

Trata-se do fato de que uma escola superior de preparação de nossas Fôrças Armadas convoca, da Província, um mestre que tem grangeado um justo galardão de competência e seriedade nos estudos políticos, porque quer ouvir o seu depoimento sôbre um tema vital para as fôrças Armadas, responsáveis primeiras pela segurança nacional do Brasil.

18. Muito significativo é que após três legislaturas como depútado estadual pela U.D.N. o prof. Nelson Sampaio tenha renunciado a sequer concorrer à reeleição. Quer parecer-nos que tal desistência da participação política pode ser imputada à contradição vital em que se encontrava um liberal puro, amante do voto consciente e pessoal, vendo-se na contingência de beneficiar-se da engrenagem clientelística do coronelismo. Tal estado de coisas não poderia ser vivido sem angústia por alguém tão respeitàvelmente preocupado com a coerência e os princípios éticos. Representando uma ideologia entre nós identificada socialmente com a das elites politicamente decadentes, por mais coerente, pura e digna que fôsse - como o foi - a doutrinação política do deputado da U.D.N., ela não foi capaz de angariarlhe a soma de votos suficiente - que só a liderança das massas lhe poderia proporcionar - para lograr um desvinculamento da originária engrenagem coronelística a que deveu, em grande parte, suas sucessivas eleições. Sua mensagem não tendo podido imantar as massas (que já se encontravam, há muito, atraídas por outras motivações que não as puramente idealistas e moralistas do liberalismo) o Mestre de teoria política não pôde lograr a eficácia que a política requer e que nem sempre os princípios alcançam. 
Não seria de supor que aquêle departamento universitário de nossa aparelhagem de segurança nacional teria chamado um técnico no saber político para ouvir-lhe um conselho prático, uma norma, uma diretriz de eficácia, ou pelo menos o equacionamento empírico particularmente nacional do binômio proposto — as doutrinas políticas e a segurança nacional?!

Não nos parece excessivamente aventurada essa interpretação.

Mas, muito longe desse caráter instrumental está o espírito de análise que o prof. Nelson Samparo serviu aos militares brasileiros naquela conferência. Passa-se por alto a circunstância nacional que será referida apenas acidentalmente. Descura-se por inteiro a nossa situação de país subdesenvolvido, de mundo periférico, bem como o fenômeno omnipresente do imperialismo, de inequivoca significação para a nossa segurança nacional, na hipótese também não ventilada - de poder ser ou vir a ser nacional essa defesa ou segurança.

Em resumo: o Brasil não conta para nada, nem, por suposto, a aparelhagem de segurança nacional dêsse país ali presente como mero público de alunos que poderia ser o mesmo dos estudantes de nossa Faculdade numa aula de Teoria do Estado.

O espírito da conferência não refoje ao espírito didático das classificações e relações gerais, exposição das doutrinas politicas contemporâneas, considerações universais sôbre o poder atuante das ideologias e ainda mais genéricas sôbre a interferência dessas ideologias sôbre a segurança nacional in abstracto, e, finalmente a ponderação das doutrinas políticas - a democracia, o socialismo, o totalitarismo, o nacionalismo e o pacifismo - e de seu influxo sôbre a guerra e a $\operatorname{paz}^{19}$.

19. Para uma comparação que esclareça o sentido de nossa crítica à falta de instrumentalidade dessa peça realmente egrégia do teoria política que é a aludida conferência, serviria às maravilhas uma conferência pronunciada um ano após, pelo sociólogo baiano 
A mais recente obra do prof. Nelson Sampaio situa-se no terreno da sociografia política e marca, portanto, uma tentativa de reconciliação com a realidade que o cerca. Trata-se da pesquisa de sociologia política intitulada $O$ Diálogo Democrático na Bahia, editada em Belo Horizonte pela Revista Brasileira de Estudos Políticos de que o professor baiano é co-diretor.

Nesse trabalho, seguindo o modêlo descrito da sociologia eleitoral em voga, o prof. Nelson SAMPAIO apresenta um retrato da vida política baiana em especial após a redemocratização, embora contendo constantes referências ao sistema e hábitos políticos da República velha.

Não tenta, porém, nesse ensaio de abordagem teórica à prática política, de que tem sido observador participante, altamente categorizado, encontrar as linhas diretrizes da evolução política local, desconhecendo, por completo, o fato da existência entre nós da mesma divisão supra-partidária que hoje assinala a política brasileira, inclusive a baiana. Referímo-nos à ideologia desenvolvimentista ou nacionalista de um lado, e às formas amorfas e inconfessas de resistência a essa ideologia, de outro. Em vez de anotar êsse fato inconteste da vida política brasileira e que no Estado repercutiu visivelmente na última campanha sucessória onde os três candidatos ao posto de governador porfiaram por identificar a sua campanha com as teses centrais do nacionalismo - o que é de fato inconteste -, o prof. NeLSON SAmparo, preferiu num bias juridicista indesculpável no sociólogo político, fundar tôdas as suas verificações estatísti-

GUERrEtro Ramos no auditório do Instituto Superior de Estudos Brasileiros e, por feliz coincidência, sôbre o mesmo tema, ou seja Ideologias e Segurança Nacional (ISEB, Rio, 1957). Não se pode dizer que haja menos erudição na conferência do prof. Guerreiro Ramos que na do prof. Nelson Sampaio. Uma não ficaria em nada a dever à outra no que se refere à profundidade do tratamento e conbecimento da matéria. Apenas, os comprometimentos ideológicos ém que a vida enredou os dois pensadores conterrâneos abrem ao ex-sociólogo do ISEB um horizonte muito mais largo de efetiva e instrumental criação científica. Não é, porém, aqui o lugar para analisarmos a contribui- 
cas e demais conclusões na base do quadro sociològicamente pouco significativo das legendas partidárias, isso quando a formação de partidos médios entre nós como o PR e o PL decorrem, como é sabido, de defecções pessoais e disputam internas de liderança no seio da uDN, e não de qualquer evento de real significado ideológico.

Ésse que é o maior reparo que se pode fazer a êsse estudo honesto e minudente do prof. Nelson Sampaio, também deriva daquelas implicações ideológicas acima referidas e que mais uma vez demonstraram a sua infecundidade tcórica.

Apesar disso, não há como negar que êsse estudo empírico marca - como autêntico sinal dos tempos - um esfốco sincero, por parte de um intelectual honesto, no sentido de integrar-se em sua circunstância, o que tem sido a nota dominante da "intelligentsia" brasileira depois que a sociologia da situação colonial veio pôr a nu a situação de insanável alienação a que está prêso, na colônia, o intelectual, se um esfôrço subjetivo ou pessoal de desalienação, caucionado pelo despertar nacional do seu povo, não concorre para retirá-lo dessa situação de espelhismo e inautenticidade.

Auto José de Cas'rro.

Após recente e exitoso concurso, o prof. Auto José DE Castro, já docente-livre de História da Filosofia em nossa Faculdade de Filosofia, alcançou a cátedra de Filosofia do Direito.

ção de Guerreiro Ramos à compreensão da circunstância brasileira em geral ou às vinculações das ideologias políticas com a segurança nacional, em particular, pelo simples fato de que, embora baiano e ex-aluno de nossa Faculdade de Direito, o sociólogo de A Redução Sociológica realizou-se intelectualmente em têrmos de total desvinculação da tradição teórica de nossa Faculdade emigrando para o Rio de Janeiro ainda estudante de Direito e lá, portanto, tendo sofrido influências absolutamente estranhas ao meio intelectual da Provincia. 
Sua obra de filósofo resume-se nas teses que elaborou para concorrer aos concursos de docência-livre de História da Filosofia e Filosofia do Direito e de cátedra para essa última.

No primeiro caso estão, respectivamente, a sua tese sôbre Eprcuro e sôbre a filosofia do direito de Hegel, intitulada $O$ Direito como Determinação do Absoluto, e, no segundo, a sua tese entre sociológico e filosófico-jurídica sôbre A İdeologia Jusnaturalista.

Essa última é a sua obra fundamental até aquí. Nela, inspirando-se na teoria da ideologia do marxismo e na moderna sociologia do conhecimento - mais naquela do que nesta, como veremos a seguir - propõe uma interpretação sociológica das filosofias jusnaturalistas como ideologias religiosas ou seculares que tendem a acobertar os interêsses dos detentores da propriedade privada. Nesse intento, a história do pensamento jusnaturalista, desde o estoicismo até a oNU, é perlustrada, tendo em vista o procedimento comum no marxismo de desmascaramento das ideologias.

Com êsse procedimento o prof. Auto de CASTro se aproxima muito mais da teoria da ideologia como ela foi formulada por Marx do que da moderna sociologia do conhecimento, que tende a patentear que o condicionamento ideológico é uma constante de todo pensamento, da qual ninguém pode eximir-se, disso resultando que as explicitações das raízes ideológicas de uma concepção não baste, por si só, para invalidá-la. Foi isso que o temperamento polêmico do prof. Auto de CASTro não lhe permitiu observar fazendo com que re-descobrisse como instrumento polêmico o processo de desmascaramento das ideologias, uma arma de luta de que o marxismo já se servia em pleno século xix e Helvetius e d. Holbach até antes disso.

Aliás, não apenas no ânimo polêmico, mas também do aguerrido espírito anti-religioso e anti-clerical do prof. Auto dE CASTRo reata a tradição dos anteriores catedráticos de 
Filosofia do Direito. No aspecto pròpriamente doutrinário, ao contrário, longe de prosseguir a tradição sociologista, é o iniciador do kelsenismo na cátedra, embora o seu kelsenismo tente uma fusão eclética com o marxismo como filosofia social e sociologia jurídica, fusão esta que pareceu impossivel ao prof. Orlando Gomes, como já referimos ao analisar o seu Marx e Kelsen.

Abril, 1960

\section{Bibliografia.}

Araújo, J. J. - Os princípios democráticos e a constituição de 1937 - R.F.D. - - 13 - 1938.

AYRes, JAYMe JUNQUEIRA - Contradição de métodos e unidade de fim democrático no Direito Civil Moderno - R.F.D. - v. 16 1941.

- Censura ao penar dos juristas para as instituiçóes democráticas - R.F.D. - v. $16-1941$.

- U porque das novas tendências denominadas de espiritualização, humanização e socialização do Direito - R.F.D. - v. 26 1951.

Baleeiro, Aliomar - A Política e a Mocidade - Livraria Progresso Ed. - Bahia - 19...

- Universidade, Elites e Lideres - R.F.D. - v. 28 - 1953.

BAleeiro, JAYMe - Ruy e a Emancipação Econômica do Brasil Forum - v. XIX - a. IX - fasc. 21.

BalthazAR DA Silveira, AlFreDo - Contra o voto dos analfabetos Rev. dos Tribunais - v. $56-\mathrm{n} \cdot{ }^{\circ} 2$.

Balthazar Da Silveira, Evandro - A Moral e a Religião no Direito

- Secção Gráfica da Escola de Aprendizes Artífices — Bahia - 1933.

- Os golpes frustos da fôrça contra a supremacia do Direito R.F.D. - . $22-1947$.

Barbosa, Mario Figueireid - 0 juiz e a Lei - Rev. Trib. - v. 45 - n. ${ }^{\circ} 1$.

- A Crise do Dineito - Rev. Trib. - v. 47 - n. ${ }^{\circ} 1$.

BARRETTO BASTOS, JENNER - A Filosofia do Direito e a Gnoseologia - Tip. Beneditina - Bahia - 1954.

- A Volta ao Direito Natural - R.F.D. - v. 9 - 1934. 
Bastos, Fininto Justiniano FerRetra - Os princípios de Direito Natural segundo o prof. Luiz Bridel, da Faculdade de Direito da Universidade de Tokio - R.F.D. - v. 9 - 1934.

- O jurista e a Organização Social, a Moral e a Religião R.F.D. - v. $10-1935$.

- O Estado moderno, suas funções, meios de que se serve para a consecuçāo de seus fins. A atividade jurídica $e$ a atividade. social (capítulo de um compêndio de D. Administrativo) R.F.D. - v. $31-1956$.

Botblho, Benjamim José - Noções de Sociologia e Direito - suplemento ao v. XII da Rev. Trib..

Carvalho, Jonas M. - O Direito na Sociedade - R.F.D. - v. 7 - 1932.

Carvaliho, Nicanor DE - O Syndicalismo no Estado Moderno, R.F.D. - v. $10-1935$.

Carvalio Filho, Aloysio DE - Em favor do divórcio - R.F.D. v. $18-1943$.

- Revolução e Tradição - R.F.D. - v. 23 - 1948.

CASTro, AUto JosÉ DE - O Direito como Determinação do Absoluto Salvador - Bahia - 1953.

- A Ideologia Jusnaturalista - Bahia - 1954.

- O Renascimento: seu significado para o pensamento filosófico, jurídico e político moderno - R.F.D. - v. 29 - 1954.

Clamente, ÁLvaro - A Justiça $e$ as idéias políticas através a história - Rev. Trib. - v. 37 - n. 2.

Diniz, Almachio - Genesis Hereditaria do Direito - Bahia - 1903.

- Ensaios Philosophicos sobre o Mecanismo do Direito - Typografia Bahiana - Bahia - 1906.

- A Sciencia do Direito - Bahia - 1907.

- Questões Actuaes de Philosophia do Direito (com Introdução de Clóvis Bevilacqua) - H. Garnier - Rio - 1909.

- Sociologia e Crítica - Magalhões e Moniz - Pôrto - 1912.

- Curso de Philosophia Elementar para uso dos candidatos ao Curso de Bacharel em Direito - Liv. Catilina - Bahia - 1912.

- Uma Teoria Geral do Direito ou um Curso de Encyclopedia Juridica - Liv. Catilina - Bahia - 1913.

- Três Estudos Sôbre Organização e vida Municipais - Bahia 1914.

- Uma Objectividade Nova do Direito: O Direito dos Soviettes Rio - 1930.

- Por uma Ditadura Militar - Rio - 1930.

- A Idéia Republicana nos meus Princípios Philosophicos - Rio -1932 . 
- S. Paulo e a Sua Guerra de Secessão - Pongetti - Rio - 1933.

- Sociologia Soviética - Schema Editora - Rio - s.d.

DUARTE, Nestor - $O$ Direito, Noção e Norma - Calvino Filho Distribuidor - Bahia - 1933.

- A Ordem Privada e a Organização Política Nacional - Cia. Ed. Nacional - S. Paulo - 1939.

- Reforma Agrária - Min. da Educação e Saúde - Serviço de Documentação - Rio de Janeiro - 1953.

- Os Fundamentos Morais da Ordem Juridica Atual - R.F.D. - v. 9 - 1934.

- A Lei no Conceito de Duguit - R.F.D. - v. 10 - 1935.

- Os Fundamentos do Direito Natural e as Direçōes do Positivismo Jurídico - R.F.D. - v. 16 - 1941.

- O Princípio da Igualdade Perante a Lei - R.F.D. - v. 28 - 1953.

- Ruy e o Processo Cultural Democrático - Rev. Trib. - v. XIX - a. IX - f. 21.

FARIA, ROGÉrIo GORDILHo DE - O Judz Inglês - R.F.D. - v. 7 1932.

- Os Juízes e a Justiça - R.F.D. - v. 10 - 1935.

- Justiça Real - R.F.D. - v. 13 - 1938.

- Nazismo e Direito - R.F.D. - v. 19 - 1934.

- Clovis Bevilacqua e a Aplicação do Direito - R.F.D. - v. 21 - 1946.

- O Sentido Humanista do Direito - R.F.D. - v. 23 - 1948.

- Humanizaçáo do Direito - R.F.D. - v. $24-1949$.

- Direito de Juristas - R.F.D. - v. 29 - 1954.

- A Finalidade da Justiça - R.F.D. - v. $30-1955$.

Filgueiras, Leovigildo IpIranga do AMORIM - Compêndio de Filosofia do Direito - Bernardo da Cunha e Cia. - Bahia - 1900.

- Estudos de Filosofia do Direito - M. Orosco e Cia. - Rio 1904 .

Fraga, Alberico —A fallencia da Democracia - R.F.D. - v. 8 1933.

- Democracia e Constituição - R.F.D. - v. 12 - 1937.

Franco Sobrinho, MANoEl DE OLIVEIRA - O Conceito de Administração na Filosofia Juridica - R.F.D. - v. 18 - 1943.

Gomes, ORlando - O Estado e o Individuo - Bahia - 1933.

- A Crise do Direito (Ensaios) - Papelaria Vera-Cruz - Bahia - 1945 .

- Raizes Históricas e Sociológicas do Código Civil Brasileiro ed. da Liv. Progresso Ed. - Universidade da Bahia - Bahia - 1958. 
- Marx e Kelsen - ed. da Liv. Progresso Ed. - Universidade da Bahia - Bahia - 1959.

- Materialismo Histórico e o Direito - ed. do CARB - Bahia - 1951.

- As Classes Sociais na Formação do Direito - ed. mimeografada pelo CARB - Bahia - s.d.

- Variações sobre a reforma do Código Civil - ed. mimeografada pelo CARB - Bahia - s.d.

- A Evolução do Direito Privado e o Atraso da Técnica Jurídica - ed. mimeografada pelo CARB - Bahia - s.d.

- O Direito Privado aos Países Socialistas - ed. do CARB Bahia.

- O Conteúdo de Classe do Direito Civil - R.F.D. - v. 10 1935.

- Aspectos da Democratização do Direito - R.F.D. - v. 12 1937.

- Uma revolução estrutural no Direito Civil - R.F.D. - v. 16 - 1941.

- $\dot{A}$ luz dos Novos Tempos - R.F.D. - v. $22-1947$.

- Aspectos da Crise do Direito - R.F.D. - v. 26 - 1951.

- Influência do Direito Público sôbre o Direito Privado - R.F.D. - v. 30 - 1955.

- O Dever das Elites - R.F.D. - v. $30-1955$.

- A Crise da Justiça - Rev. Trib. - v. 49 - n. 3.

- Significado da Evolução Contemporânea do Direito de Propriedade - Rev. Trib. - v. 48 - n. 1.

GONGALVES, ADkRBAL - Da Renovação dos Valores Éticos-Jurídicos R.F.D. - v. 30 - 1955.

- A valorização do Direito através da sentença - Rev. Trib. v. $38-n .^{\circ} 6$.

GuIMARĀES, JoÃo AlFreDo $\rightarrow$ O Direito - R.F.D. - v. 8 - 1933.

- Quando o juiz cria a norma jurídica a ser aplicada a um caso concreto procede como legislador - R.F.D. - v. 15 - 1940.

Lemos, VIRgiLio DE - O Conceito de Soberania - Typografia Bahiana - Bahia - 1900 .

- Da Classificação dos Conhecimentos Humanos e das Sciencias Juridicas - Imprensa Official do Estado - Bahia - 1916.

LIMA, HeRmes - Conceito Contemporâneo de Sociologia - Imprensa Official do Estado - Bahia - 1925.

- Introdução à Ciência do Direito - Rio - várias edições.

MAchado, AUGUSto AlexandRe - $O$ Liberalismo Economico $e \quad o$ Proletariado - Casa Ramalho - Maceió - 1935.

- População e Miséria - R.F.D. - v. 20 - 1945. 
- A Organização do Trabalho e a Vida dos Trabalhadores R.F.D. - v. $21-1946$.

- As Escolas Economicas e a Evolução da Economia Política R.F.D. - v. 26 - 1951.

- O Movimento Corporativo e a noção de Liberdade - Forum v. XII - a. V - fasc. 5 .

- O Materialismo de Marx e a Vitória Espiritual do Mundo Forum - v. XVIII - a. VII - f. 16.

Machado, Hermano Augusto Palmeira - O Mercantilismo - R.F.D. - v. 30 - 1955.

Machado Neto, A. L. - Sociedade e Direito na Perspectiva da Razão Vital - Liv. Progresso Ed. - Bahia - 1957.

- Sociologia do Direito Natural - Liv. Progresso Ed. - Bahia 1957.

- Para Uma Sistematização das Ciências do Direito - Separata de "Tecnica" - n. ${ }^{\circ} 38-1957$.

- o Problema da Ciência do Direito - Liv. Progresso Ed. Bahia - 1958.

- A Sociologia Jurídica da Escola Objetiva Francesa - in Atualidade de Durkheim - ed. da Liv. Progresso Ed. - Univ. da Bahia - Bahia - 1959.

- Nova Filosofia da Interpretação do Direito - in Rev. Brasileira de Filosofia - S. Paulo - v. VII - fasc. I - n. ${ }^{\circ} 25$ - 1957.

- Introdução à Ciência do Direito como Disciplina Epistemológica - Rev. Bras. de Filosofia - v. IX - fasc. III - n. ${ }^{\circ} 35$ 1959.

- A Ordem Jurídica e o Desenvolvimento Econômico - ed. mimeografada - Bahia - 1960.

MARINHO, JoSAPHAT - O Direito e as suas causas geradores - R.F.D. - v. 12 - 1937.

- Diretrizes do Pensamento Jurídico e Político de Filinto Bastos - R.F.D. - v. 31 - 1956.

- Conteúdo, Valor Jurídico do Preâmbulo das Constituições Rev. Trib. - v. $50-$ n. ${ }^{\circ} 3$.

- Função Criadora da Jurisprudência - Forum - v. XVI a. VII - f. 13.

- O Jurista e a Renovação do Direito - Rev. Trib. - v. XXI a. XIII - f. 23-25.

MARqUES DOS REIS, JOÃO $-O$ Desarmamento Moral e a Missão dos Juristas - R.F.D. - v. 8 - 1933.

MoREIRA FILHo, JoÃo - Justiça e Democracia - R.F.D. - v. 18 -1943 . 
NASCIMENTO JUNqUeira, JoÃo J. - O Primado Supremo do Direito - R.F.D. - v. 7 - 1932.

Nogugra, Adalicio CoEH $\longrightarrow$ Concepção de Direito Natural entre os Romanos - R.F.D. - v. 23 - 1948.

- Direito e Moral - R.F.D. - v. $25-1950$.

- Direito e Idealismo - Rev. Trib. - v. 41 - n. ${ }^{\circ} 1$.

Palmbira, Sinval - Capitalismo e Democracia - Forum - v. XII - ap. V - f. 1 .

Paranhos, Fernando Gomes de Freitas - O Fundamento do Direito Internacional - R.F.D. - v. 8 - 1933.

RAmos, Claudionor - Sôbre a livre manifestação do pensamento R.F.D. - v. 9 - 1934.

SÁ, Julio VIEIRA DE - Integralismo e Medievalismo - R.F.D. n. $8-1933$.

SÁ Phreira, Gabriella lefal de - O Contágio do Crime - R.F.D. - v. 7 - 1932 .

SAMPAIO, Nelson DE Souza - As Idéias - Fôrças da Democracia Imprensa Regina - Bahia - 1941.

- A Desumanização da Política - Liv. Progresso Ed. - Bahia - 1951.

- Ideologia e Ciência Política - Liv. Progresso Ed. - Bahia - 1953.

- A Arte de Ser Livre - Liv. Progresso Ed. - Bahia - 1957.

- O Diálogo Democrático na Bahia - ed. da Rev. Bras. de Estudos Políticos - Belo Horizonte - 1960.

- As Doutrinas Políticas Contemporâneas e suas Relações com a Seguranca Nacional - Escola Superior da Guerra - Rio 1956.

- Nosso Mundo de Contradições - R.F.D. - v. 16 - 1941.

- A Evolução do Estado - R.F.D. - v. 21 - 1946.

- As Duas Faces de Comte - R.F.D. - v. 30 - 1955.

- Carrell e a Democracia - Forum - v. XV - ano VI - f. II.

- O Parlamentarismo e a Realidade Brasileira - Rev. Bras, de Est. Pol. - n. ${ }^{\circ} 5-1959$.

- Eleições Baianas - Rev. Bras. de Est. Pol. - n. ${ }^{\circ} 8$ - 1960.

Santos, Milton - As Instituições Políticas e o Direito - Forum - v. XXI - ano XIII - fasc. 23-25.

SchlaEPFER, LAURA - O Direito e a Moral - R.F.D. - v. 9 - 1934.

- A Enciclica Rerum Novarum - Forum - v. XIV - ano VI - fasc. 9.

Silva, Adhemar Raymundo DA - Sociedade, Nação, Estado - R.F.D. - n. ${ }^{\circ} 8-1933$. 
Simas SARAIVA - O Direito na sua formação e Interpretação - Rev. Trib. - v. $58-$ n. ${ }^{\circ} 2$.

Souza Dantas, Carlos Fernando DE - O Direito e o Estado - Modernas Teorias - Rev. Trib. - v. 32 - n. ${ }^{\circ} 6$.

Spínola, Clovis - O Poder Judiciário na Democracia - Rev. Tribs. - V. 37 - n. 4.

Tourinho, Demetrio CyRIAco FERREIRA - Direito Livre, Direito Justo - R.F.D. - v. $13-1938$.

Valente, Silvio - Tarde e o Atavismo Moral - R.F.D. - n. ${ }^{11}$ - 1936.

Vianna FILHo, LuIZ - Um Olhar Sobre o Direito - Forum - v. XIV - ano VI - fasc. 8. 